\title{
COMUNAS AND INDIGENOUS PROTEST IN CAYAMBE, ECUADOR*
}

The 1930s was a period of slow and painful capitalist formation in the Ecuadorian highlands. Marginalized Indigenous peoples ${ }^{1}$ who lived in rural areas particularly felt this economic transition as modernizing elites utilized their control of state structures to extend their power to the remote corners of the republic. It was also a time of gains in social legislation, including new laws which dealt with the "Indian problem." One of the primary examples of this type of legislation was the 1937 Ley de Comunas which extended legal recognition to Indian communities. In certain parts of the country such as in the central highland province of Chimborazo, Indigenous peoples quickly embraced this comuna structure and formed more comunas than any other area of the country (see Map 1). In similar situations in the neighboring countries of Colombia and Peru, Indian villages also used legal frameworks which the government imposed on their communities to petition for ethnic and economic demands. ${ }^{2}$

\footnotetext{
* Earlier versions of this paper were presented at the 1997 meeting of the Midwest Association for Latin American Studies (MALAS) in St. Louis, Missouri, October 30-November 1, 1997, and the 49th International Congress of Americanists, Quito, Ecuador, July 7-11, 1997. Support for this research during the summer of 1997 in Ecuador was provided by the American Historical Association's Albert J. Beveridge Grant. The author would like to thank Licenciado Nogales for facilitating access to the comuna records at the Dirección Nacional de Desarrollo Campesino, Ministerio de Agricultura, and Cynthia Radding, Kim Clark, and Silvia Alverez for their comments on an earlier draft.

${ }^{1}$ The use of a capital " $\mathrm{I}$ " in reference to Indigenous peoples in this document is intentional and represents a strong affirmation of ethnic identity on the part of the protagonists. Furthermore, the plural "peoples" indicates the broad diversity among Indigenous groups not only in Ecuador but throughout the Americas.

${ }^{2}$ See Joanne Rappaport, Cumbe Reborn: An Andean Ethnography of History (Chicago: University of Chicago Press, 1994) and Florencia E. Mallon, The Defense of Community in Peru's
} 


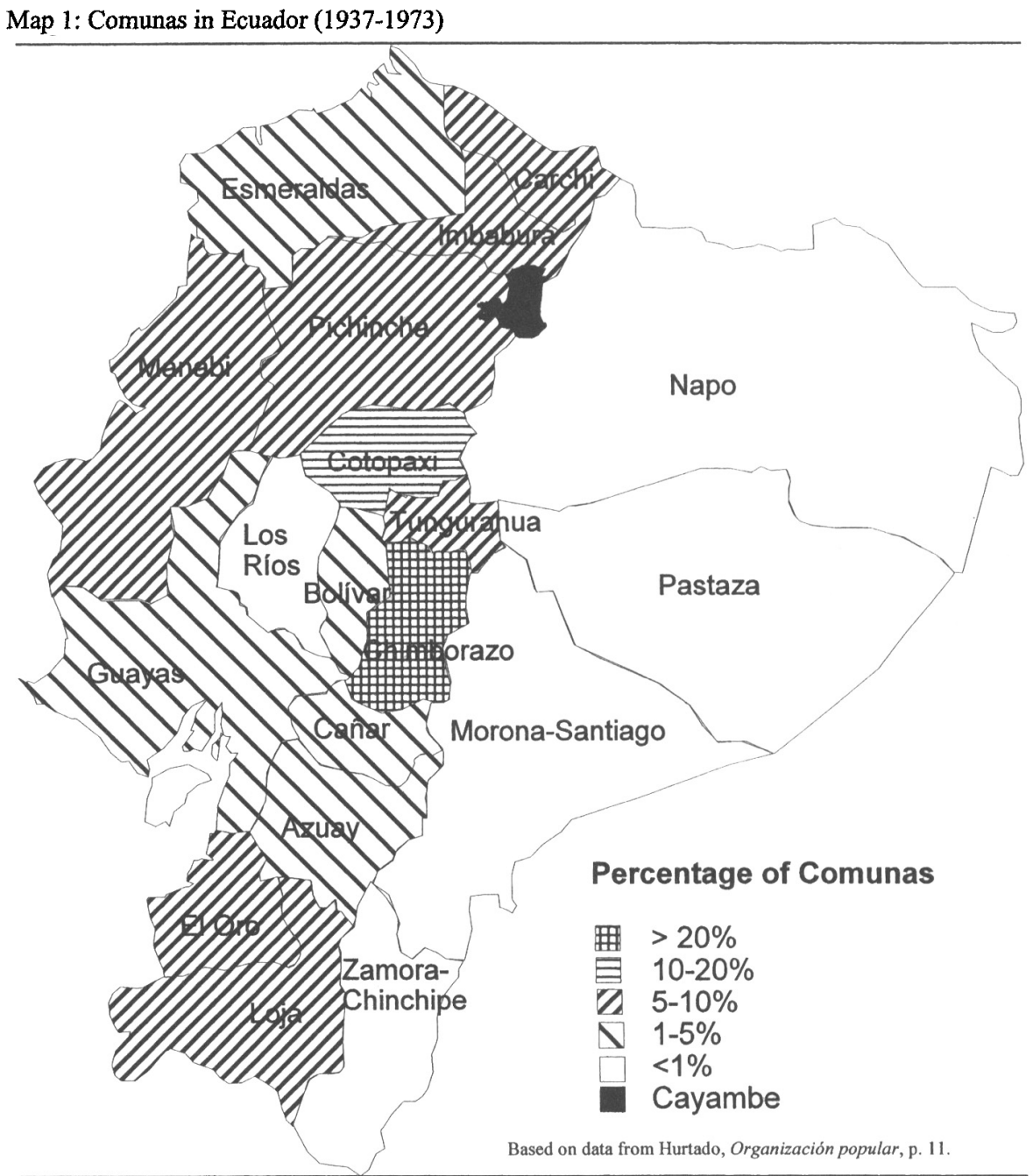

This essay examines the impact of the comuna legislation on Indigenous protest movements in the canton of Cayambe in the northern Ecuadorian highlands. In the 1920s and 1930s, some of the first and best organized rural political organizations in Ecuador emerged in this canton. Indians on the expansive Pesillo hacienda formed militant unions which resulted in a protracted strike in 1931 over wages and

Central Highlands: Peasant Struggle and Capitalist Transition, 1860-1940 (Princeton: Princeton University Press, 1983). 
working conditions that gave birth to Ecuador's modern Indian movement. ${ }^{3}$ Nevertheless, Indigenous activists in Cayambe shunned the comuna law and refused to take advantage of its provisions in order to advance their political goals. Even today, in communities with radical histories of political organization, there is little interest in forming comunas. The only areas of Cayambe which have formed comunas were communities on the southern periphery of the northern core rural protest activities in the 1930s. To date not a single comuna has been formed in the area of Pesillo which was a center of radical organizational activity in the 1930s when the central government initially promulgated this law (see Map 2).

Why, despite the apparent advantages of legal recognition, did Indigenous peoples in Cayambe refuse to utilize the comuna form of organization to advance their rural organizing efforts? On the surface, this law appeared to have as its intent the defense of local community interests. It would provide them with a legitimate conduit through which to agitate for and secure their demands from the central government. Roberto Santana maintained that non-compliance throughout Ecuador was due to a variety of functional reasons such as ignorance of the law, difficulty with the paperwork, racial discrimination, and pressure from hacendados. ${ }^{4}$ In the case of Cayambe, all of these explanations come up short. Searching for a satisfactory interpretation can explain much about the nature of social organization and ethnic identities in Cayambe and the basis which these provided for social protest.

Indians in Cayambe did not fail to comply with the decreed comuna structures because of a lack of organization or leadership skills. Dolores Cacuango, Jesús Gualavisi, and others from this period are renowned for their abilities to organize strong community movements. It was not due to the remoteness of Indian communities. By the 1930s a developing transportation and communications infrastructure brought national and international capitalistic economic and political forces to

\footnotetext{
${ }^{3}$ See Marc Becker, "Una Revolución Comunista Indígena: Rural Protest Movements in Cayambe, Ecuador," Rethinking Marxism 10:4 (forthcoming Fall 1998) and Mercedes Prieto, "Haciendas estatales: un caso de ofensiva campesina: 1926-1948," in Ecuador: cambios en el agro serraño, Miguel Murmis et al, eds., (Quito: Facultad Latinoamericana de Ciencias Sociales (FLACSO) - Centro de Planificación y Estudios Sociales (CEPLAES), 1980), pp. 101-30.

${ }^{4}$ Roberto Santana, ¿Ciudadanos en la etnicidad? Los indios en la política o la política de los indios, Francisco Moscoso, trans., Colección Biblioteca Abya-Yala 19 (Quito: Ediciones AbyaYala, 1995), p. 112.
} 
○ Otavalo

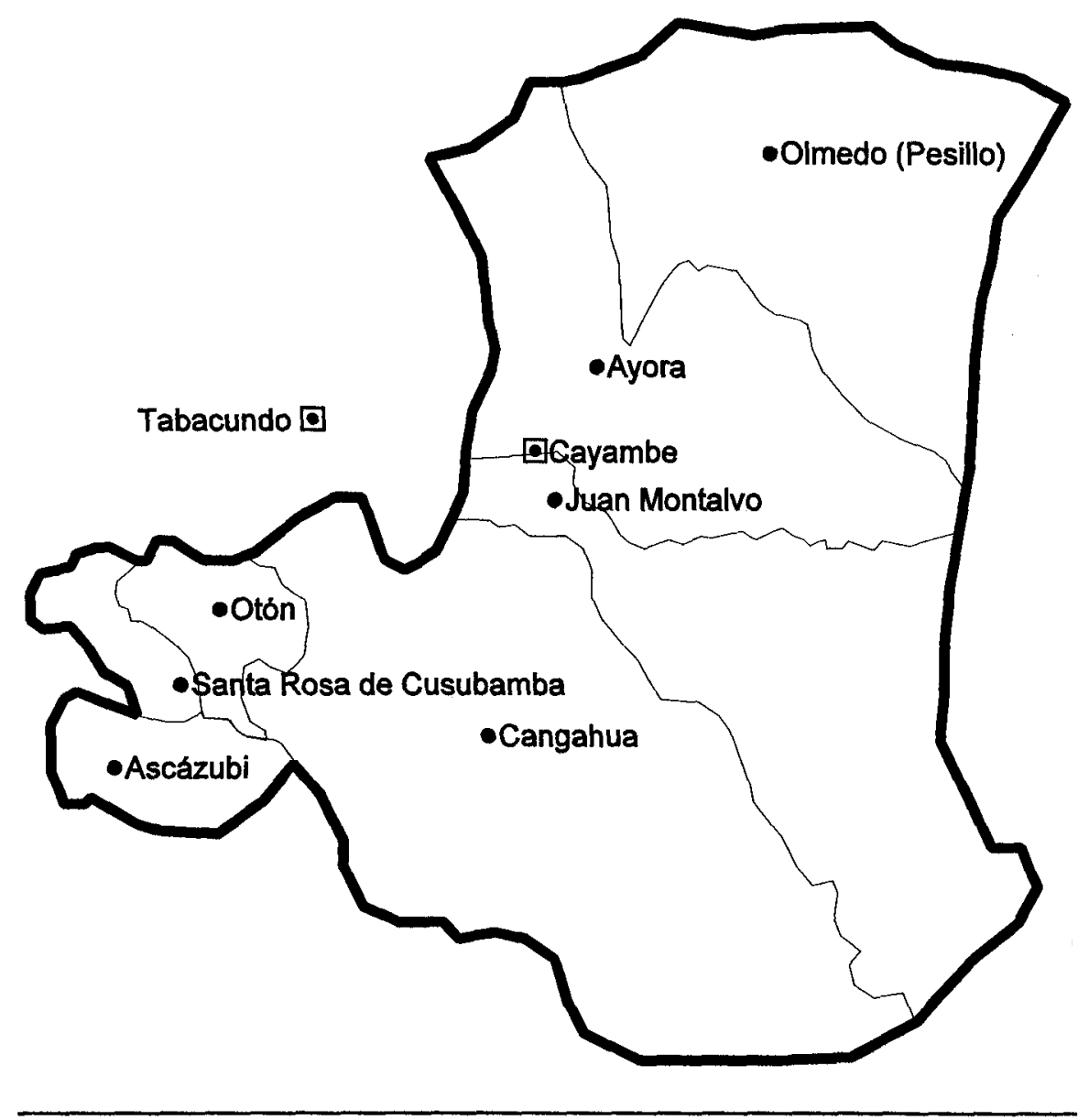

bear on this area. Nor was non-compliance due to resistance to outside intrusion into their traditional lifestyles. During this time these Indians were actively establishing alliances with urban leftists, labor leaders, and others willing to help secure for themselves more rights and a larger role as Indians and rural workers in the national culture. Why, then, this studied disinterest toward legislation which theoretically advanced a defense of Indian concerns? 
The government primarily targeted free Indian communities which held common resources such as land and water with this legislation. Over the centuries, many Indians (including those in northern Cayambe) had lost their land and now worked on haciendas in a system of debt peonage and service tenancy relations called the huasipungo system. This law did not intend for these huasipungueros who did not own land to form comunas. After agrarian reform legislation in 1964 abolished the huasipungo system and gave some Indians back their land, there was a virtual explosion in the number of comunas in other highland regions like Chimborazo as former huasipunguero communities adopted this form of social organization. ${ }^{5}$ This same phenomenon, however, did not occur in Cayambe. Particularly in areas with the highest levels of activism, Indians chose to form cooperatives which allowed for more worker control over the means of production. They found the comuna form of organization inappropriate and undesirable for their situation, and the legislation failed to address critical issues which they faced.

Rather than embracing the formation of comunas as a way to achieve community empowerment, politically astute Indigenous leaders in Cayambe understood the law's intent to extend state structures into traditional communities with an ultimate goal of paternalistically manipulating local affairs. Activists interpreted this legislation as a means for the elite to assimilate rural Indian communities into the emerging dominant blanco-mestizo culture and to undermine nascent leftist organizing efforts. This was part of a larger struggle for control over the nature of society which was emerging in Ecuador. Would the country develop a western capitalist economy in which the wealth of the country would benefit a small elite? Or would economic production and political control be oriented toward local concerns and issues which would improve the lives of the country's large marginalized and impoverished rural Indian masses? Indians in Cayambe rejected the provisions of this law precisely because they wanted to defend their political space and economic interests, and to preserve their ethnic identity.

\section{Ley de Comunas}

A proper understanding of the Indian activists' rejection of the comuna legislation must be placed in its broader political context.

\footnotetext{
${ }^{5}$ Tanya Korovkin, "Indigenous Peasant Struggles and the Capitalist Modernization of Agriculture: Chimborazo, 1964-1991," Latin American Perspectives 24:3 (94) (May 1997), p. 29.
} 
Throughout the Americas in the 1930s, intellectuals and politicians advocated a variety of indigenista policies which they believed would solve the "problem" of marginalized Indigenous populations through government-sponsored and controlled programs of integration into the dominant society. In Mexico, Lázaro Cárdenas enacted aspects of the 1917 constitution which recreated and preserved the communal ejido lands under government protection. In the United States, John Collier implemented the 1934 Indian Reorganization Act (IRA), which restructured tribal governments. This legislation placed in power a group of elite assimilated reservation politicians trained in western management styles. The result was a conflict between "traditional" leaders who wanted to preserve their culture and ethnic identity, and "progressive" leaders who wanted to introduce new and modern methods of governance. ${ }^{6}$ In both cases, elite white politicians subjugated the concerns of the Indigenous peoples to their own economic and political interests.

The Ecuadorian government promulgated the Ley de Comunas during a time of political turmoil and social unrest as elites fought for control of state power. Twenty-one different chief executives occupied the presidency between 1931 and 1948 and not one managed to complete a term in office. At the same time, there was growing support for leftist political parties. After José María Velasco Ibarra fell from power for the first of four times in 1935, Federico Páez served as president for two years. Páez was not formally affiliated with any political party, although he did betray some leftist sympathies. He initially enjoyed support from some socialists and included two socialist ministers in his government. He passed a variety of legislation which dealt with social issues, including a labor law, social security, and a national welfare institute. Under the motto "social evolution, yes, social revolution, no," he also proposed minor reforms of the country's land tenure system. After a military uprising against his government, however, Páez became much more dictatorial. He created an atmosphere of repression, suspended civil liberties, restricted freedoms of expression, imprisoned and exiled his opponents (first from the right and then from the left), and named a Nazi to the head of the police. It was in this atmosphere and toward the end of his government that Páez

\footnotetext{
${ }^{6}$ Alvin M. Josephy, Jr., Now That the Buffalo's Gone: A Study of Today's American Indians (New York: Knopf, 1982), pp. 219-20.
} 
dictated the Ley de Organización y Régimen de Comunas (commonly called the Ley de Comunas or Law of Communes) on July 30, 1937.7

Páez articulated a notably liberal assimilationalist attitude in explaining the purpose for this legislation. First, the existing Law of Territorial Division only recognized the larger administrative units of province, canton, and parroquia (civil parish), and there was a need to incorporate the smaller population centers (which alternatively went under the names caserios, anejos, barrios, partidos, comunidades, or parcialidades) into the nation-state. As a result, comunas were not grassroots organizations, but part of the political-administrative structure of the state apparatus. Second, Páez believed the government should legally recognize these population centers in order to assure their social development. Finally, this administrative structure was necessary to tend to the moral, intellectual, and material development of communities. ${ }^{8}$ The social welfare minister's report for 1937 highlights the ideology underlying this law which originally was to be called the Ley de Comunidades Indígenas y Montuvias. ${ }^{9}$ The law does not articulate a desire to protect traditional community structures or grant Indians more autonomy over their local affairs. The legislation was the outgrowth of years of debate on how to resolve the "Indian problem" that ever since the colonial period weighted heavily on the country and prevented its progress. The government rejected the idea of dissolving communities and distributing land to individual Indians. Despite the attractiveness of this proposal, this would degenerate into interminable conflicts and ultimately hurt national cohesion. Rather, the land would be brought under ministerial control in order to oversee their activities.

The promulgation of the comunas law in 1937 was not the first time that the government considered imposing such structures. In 1930, the government began plans to delineate the boundaries of Indian com-

\footnotetext{
${ }^{7}$ Patricio Ycaza, Historia del movimiento obrero ecuatoriana: De la influencia de la táctica del frente popular a las luchas del FUT, segunda parte (Quito: Centro de Documentación e Información Sociales del Ecuador (CEDIME), 1991), pp. 17-25.

8 "Ley de Organización y Régimen de las Comunas" (Decreto no. 142), Registro Oficial, No. 558 (August 6, 1937), p. 1517.

${ }^{9}$ Virgilio Guerrero, Ministerio de Previsión Social, Trabajo, Agricultura, Colonización e Industrias, Informe que el Sr. Teniente Coronel S. Virgilio Guerrero presenta a la H. Asamblea Nacional, Quito, a 10 de agosto de 1937 (Quito: Inprenta de la Caja del Seguro de E.P. y O., 1937), p. 31. "Montuvios' are semi-acculturated peasants on the Ecuadorian coast. See José de la Cuadra, El montuvio ecuatoriano (ensayo de presentación) (Quito: Instituto de Investigaciones Economicas de la Universidad Central del Ecuador, 1937).
} 
munities in order to stop invasions of hacienda land. ${ }^{10}$ In 1933 in the aftermath of intense organizational activity in Cayambe, the Ecuadorian congress debated a "Project of Statutes for Agricultural Associations and Indigenous Communities." Rather than defending the interests of these communities, the intent of this legislation was to stop leftist organizing efforts in Indian communities and to draw the communities into the capitalist market. There was an urgent need to do this before the communities became completely enveloped in the spreading ideas of regaining the land which they had lost over the centuries to the surrounding haciendas. ${ }^{11}$

From a liberal point of view, the law was a brilliant compromise. Páez hoped that this legislation would help bridge racial divisions and create a harmonious, ethnic-blind society. It would mediate conflicts between individual and collective interests while providing a path to assimilate isolated Indians into the dominant mestizo culture. Furthermore, the law would not compromise elite privilege and in fact would insure its survival. In order to take advantage of this law, a community had to have held its land for at least thirty years. Indians trapped in the huasipungo system on haciendas could not avail themselves of this law to reclaim their lost lands. Modernizing hacendados were moving away from the feudalistic huasipungo system and towards a system of wage labor, and the comunas would provide them with a cheap and steady supply of labor, which they could exploit without having to worry about providing land, water, and other resources for their workers. The law could provide social stability in the countryside while at the same time providing for capitalist penetration and consolidation of power and wealth in the hands of a small elite. Providing land, which has always been a primary Indian demand, would undercut growing discontent that led to independent leftist and Indian organizational efforts in rural communities. The government hoped the law would stop rural protest dead in its tracks. Without these rural disturbances, agricultural production would flourish. Over twenty years later, even the social welfare minister of in the conservative Camilo Ponce En-

\footnotetext{
${ }^{10}$ Francisco J. Boloña, Informe del Ministerio de Agricultura, Previsión Social, etc., a la nación, 1929-1930 (Quito: Talleres Tipográficos Nacionales, 1930), p. 48.

${ }^{11}$ Hernán Ibarra C., La formación del movimiento popular: 1925-1936 (Quito: Centro de Estudios y Difusion Social (CEDIS), 1984), p. 71; M. R. Balarezoa, Ministro de Gobierno y Previsión Social, Informe a la nación, 1932-1933 (Quito: Talleres Tipográficos Nacionales, 1933), p. 34.
} 
ríquez government stated that the comuna had proven to be a good solution to rural Indian problems. ${ }^{12}$

In October 1938, the military replaced the increasingly dictatorial Páez with Alberto Enríquez Gallo, a nationalist military general with clear socialist leanings who enjoyed the support of a United Front of socialists and communists. ${ }^{13}$ Enríquez governed for less than a year, but managed to institute extensive social reforms during this time. Under his mandate, the government implemented the 1938 Labor Code based on the liberal 1917 Mexican constitution which articulated extensive rights for workers and peasants. He also convoked a constitutional assembly in which socialist intellectuals played a significant role, but conservative factions of the liberal party regained control of the government and prevent the passage of the progressive magna carta.

As part of this program of legislating social reform, Enríquez expedited the Estatuto Juridico de las Comunidades Campesinas (Judicial Statute of Rural Communities) on December 7, 1937. This statute expanded on the comuna legislation which Páez had promulgated four months earlier. It declared the right for rural communities to exist and provided for their social and economic development under the protective arm of the state. The paternalistic nature and intent of this law are clear; it gave the government the obligation to protect and tutor the rural communities. The social welfare ministry (Ministerio de Previsión Social) would mediate conflicts between comuneros, between members and the comuna leadership, and between comunas and neighboring private property. The ministry would carefully monitor their activities including the maintenance of "scientific statistical control," mediate any conflicts, and protect them from those who would prey on their ignorance. The legislation allowed little space for the independent development of these communities, and it would always legislate in the absence of the representation of those whom these actions most directly affected. ${ }^{14}$

\footnotetext{
${ }^{12}$ Nicolas Crespo Ordoñez and Ministro de Previsión Social y Trabajo, Informe a la naciôn, 1960 (Quito: Editorial "Espejo" S.A., 1960), p. xvii.

${ }^{13}$ Jorge Salvador Lara, Breve historia contemporánea del Ecuador, Colección Popular 502 (México: Fondo de Cultura Económica, 1994), p. 458.

14 "Estatuto Jurídico de las Comunidades Campesinas" (Decreto No. 23) Registro Oficial, Nos. 39 and 40 (December 10 and 11, 1937), p. 2388. Also see Ecuador, Ministerio de Gobierno y Previsión Social, Informe a la nación, 1938 (Quito: Imprenta del Ministerio de Gobierno, 1938), p. 18; and Enrique Malo, Ministro de Previsión Social, Memoria mayo 1939-marzo 1940 (Quito:
} 
The Ecuadorian law does not explain the choice or use of the term "comuna" except that these were communities which had access to and administered communal property. The term "comuneros" had long been commonly used to indicate members of Indigenous communities, especially those with "terrenos comunales" (communal land). The word "comuna" comes from the French word "commune," a feudal term which was synonymous with "municipality." The term implied a free city which existed under its own laws and whose inhabitants had shared interests. ${ }^{15}$ This law did not create Indian communities; it merely gave an existing institution legal recognition within the nationstate ${ }^{16}$ In reality, the use of this type of administrative structure to control the activities of local communities had long existed under different names. During the period of Spanish colonial administration, Indian communities struggled to protect their landholdings from the encroaching power of the creole hacendados. Many of these communities had managed to function without formal recognition for hundreds of years and several had gained legal recognition before the implementation of this law. ${ }^{17}$

The comuna law stipulated that all population centers with a minimum of 50 inhabitants were to incorporate themselves as comunas under the jurisdiction of the parroquia in which they were located and register the comuna with the social welfare ministry. ${ }^{18}$ Although the law mentions 50 inhabitants as the minimum size of a comuna, it does not stipulate how many of these community members needed to assemble to form the comuna. Traditionally governmental officials required a population center to have at least 50 heads of family to

Talleres Gráficos de Educación, 1940), p. 84. As president of the senate, Carlos Arroyo del Río abrogated this statute on March 4, 1939, because Indians were using its provisions to file complaints and demands. José María Velasco Ibarra reimplemented the statue on August 1, 1944. See C. Augusto Durango, Informe del Ministro de Previsión Social, 1939 (Quito: Imprenta del Ministerio de Educación, 1939), pp. 156-57, Alfonso Calderon M., Informe a la nación, junio y julio 1944 (Quito: Imprenta Nacional, 1944), pp. 13-14, and Alfredo Rubio Orbe, ed., Legislación indígenista del Ecuador, Ediciones especiales del Instituto Indigenista Interamericano, no. 17 (México: Instituto Indigenista Interamericano, 1954), pp. 97-98 and 101-102.

${ }^{15}$ Franklin Bucheli García, Régimen de tenencia de la tierra en las comunas campesinas y su legalización, Serie Textos Univeritarios, 4 (Azuay: Universidad del Azuay, 1994), pp. 15-16.

${ }^{16}$ The government understood that comunas and communities were two very different concepts. See Malo, Memoria, anexo no. 5 , p. 37.

${ }^{17}$ Víctor A. González S., charts this history in Las tierras comunales en el Ecuador (Guayaquil, Ecuador: Casa de la Cultura Ecuatoriana, Nucleo del Guayas, 1982).

${ }^{18}$ In 1959, administration of the comunas passed to the Ministerio de Agricultura y Ganaderia (Ministry of Agriculture). 
incorporate. ${ }^{19}$ The law explicitly states that both men and women from the community were to gather every December to elect the comuna's leadership for the coming year. Indeed, both men and women participated in these annual meetings and were listed on the membership roles, although men usually held leadership positions in the comuna. Placing both men and women on an equal legal footing is ironic given that in the dominant society women did not enjoy such equality. Perhaps this was merely a covert recognition of the unique nature of Indigenous societies in which gender roles were different from those in white society.

The law required each comuna to select a community council ( $c a-$ bildo) comprised of a president, vice-president, treasurer, trustee (sindico), and secretary. These were unpaid, voluntary positions. The officers, who were to be honorable and morally upright, met the first Sunday of every month to administer the community's affairs and to look after the moral, intellectual, and material well-being of the community members. Few other restrictions were placed on who could fulfill these posts; a comuna's bylaws would occasionally mention that the president was to be at least twenty-five years old and the secretary needed to be literate in order to carry out the functions of that office. The law allowed for indefinite reelection for these positions. The president and secretary of the cabildo were to maintain a registry of everyone who lived in the comuna as well as an inventory of the communal property. They were to submit copies of these registries and inventories to the social welfare ministry in Quito.

Comunas were permitted to hold collectively material goods, which benefitted the entire community, such as pasture and farm land, industries, irrigation canals, tools, and schools. If the community needed investment capital for an agricultural project, pending governmental approval they could mortgage communal property for a line of credit from a bank. The law did not include ethnic language or indicate that only Indians were to form comunas, even though it implicitly targeted Indians and emerged out of a context of elite discussions of how to resolve the "Indian problem." In reality, over time many different types of communities formed a variety of comunas. Not all Indians formed comunas, and poor whites and mestizos living in rural areas and marginalized urban barrios also availed themselves of the provi-

\footnotetext{
${ }^{19}$ Bucheli, Régimen, p. 18.
} 
sions of this legislation. Comuneros were involved in a variety of economic activities in addition to agriculture. On the coast, many comunas were dedicated to fishing. Members of the Santa Clara comuna located on the urban periphery of Quito worked as bus drivers and brick layers. ${ }^{20}$ Nevertheless, as indicated by and perhaps encouraged with the judicial statutes governing comunas in rural communities, the vast majority of comunas were formed in highland Indian communities. ${ }^{21}$ Through the second agrarian reform in 1973, 1,604 communities throughout the country formed comunas. The vast majority ( 80 percent) of these were in the highlands, with most of the rest on the coast and only eight in the eastern Amazon region. Most of these comunas were in Chimborazo (331 comunas, or over 20 percent of the country's total), with a large number ( 214 comunas or 13 percent) in Cotopaxi. Pichincha, the province to which the canton of Cayambe belonged, also contributed a significant number of comunas $(148$, or almost 10 percent) (see Map 1).

In the late 1930s after the passage of the law, there was a virtual explosion in the number of legally recognized comunas as communities scrambled to comply with this new legislation (see Figure 1). Nevertheless, many communities failed to elect cabildos, so in January of 1938 the government allowed another year to comply with this law.22 Although the Ley de Comunas dictated that all communities were to form comunas, and although Cayambe had a long history of grassroots organizations, this form of political organization remained rare in the canton. In 1938, one year after the passage of the law, 255 comunas

\footnotetext{
${ }^{20}$ Osvaldo Hurtado and Joachim Herudek, La organización popular en el Ecuador (Ecuador: Instituto Ecuatoriana para el Desarrollo Social (INEDES), s.f.), p. 19. For a general discussion of comunas, see Luciano Martínez V., "Sobre el concept de comunidad," Cuadernos de la realidad ecuatoriana: El problema indígena hoy (Centro de Investigaciones de la Realidad Ecuadoriana, CIRE, Quito) 5 (1992), pp. 71-79. For a detailed analysis of coastal comunas, see Silvia G. Alvarez, Los comuneros de Santa Elena: tierra, familia y propiedad, Biblioteca de ciencias sociales; v. 34 (Ecuador: Corporación Editora Nacional, Ediciones Abya-Yala, 1991).

${ }^{21}$ Osvaldo Hurtado observed a high degree of correlation between the formation of comunas and areas of the country with a high density of Indigenous peoples. Hurtado, Organización popular, p. 12. Leon Zamosc revisits these same issues and questions in Estadistica de las áreas de predominio étnico de la sierra ecuatoriana: Población rural, indicadores cantonales y organizaciones de base (Quito: Abya Yala, 1995).

${ }^{22}$ Alfredo Rubio Orbe, ed., Legislación indígenista del Ecuador, Ediciones especiales del Instituto Indigenista Interamericano, no. 17 (México: Instituto Indigenista Interamericano, 1954), p. 96. The law, however, never established penalties for communities which failed to comply with this legislation. In 1940, the government made clear its intent to register new comunas on an ongoing basis. Malo, Memoria, p. 82.
} 


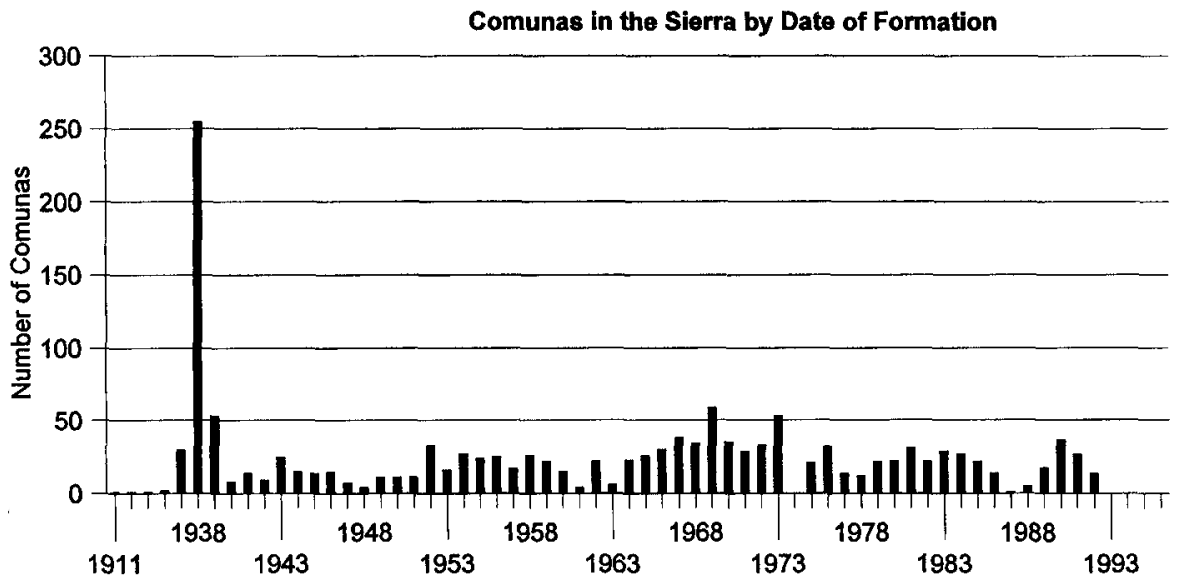

Figure 1: Source: Leon Zamose, Estadistica de las áreas de predominio étnico de la sierra ecuatoriana: Población rural, indicadores cantonales y organizaciones de base (Quito: Abya Yala, 1995). pp. 90-91.

formed throughout the highlands but only one appeared in Cayambe. From the promulgation of the comuna law until agrarian reform in 1964 , only six communities in this canton adopted the comuna structure (see Appendix and Figure 2). This was a minuscule percentage of

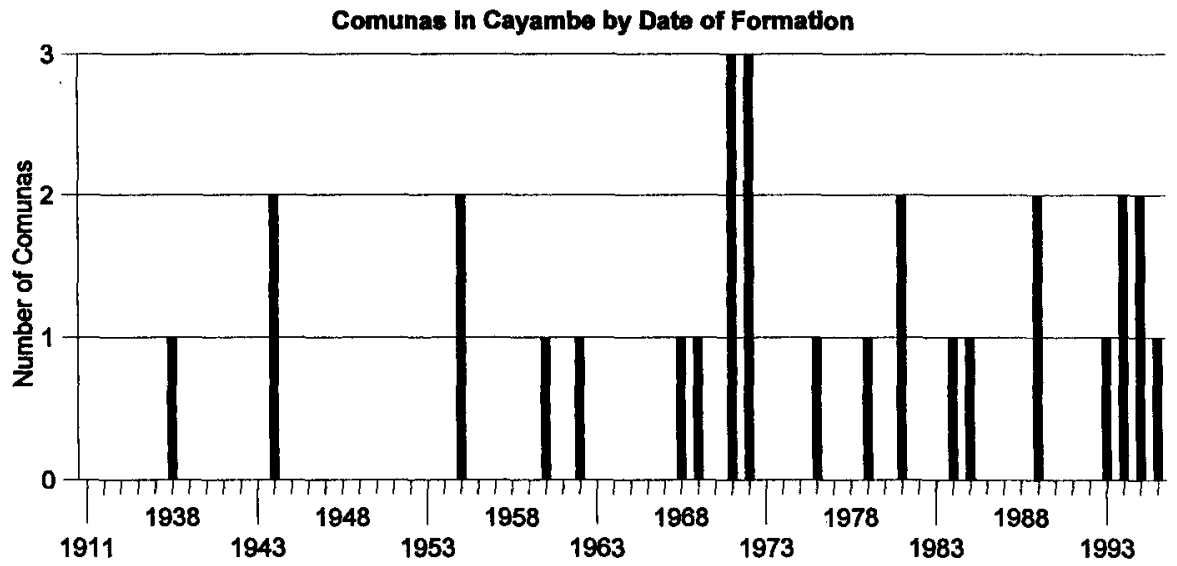

Figure 2: Source: Comunas Jurídicas de la Provincia de Pichincha, Cantón Cayambe, Dirección Nacional de Desarrollo Campesino, Ministerio de Agricultura, Quito. 
the total number of comunas formed during these years. ${ }^{23}$ In the ten years after the 1964 agrarian reform during a time of one of the highest levels of activism in terms of the formation of rural organizations, and in the context of huasipungo communities elsewhere in the country rapidly forming comunas, only eight more emerged in Cayambe. This was not even 1 percent of the country's total number of comunas. This was one of the rare times that Cayambe followed rather than led rural organizational efforts in Ecuador.

Contrasting the nature, history, and experiences of two comunas in Cayambe reveals why most Indian communities in Cayambe rejected the comuna structure. The first, Ascázubi Alto, was in many ways typical of the comunas formed in the Ecuadorian highlands during the first decades that the law was in effect. The second, Eloy Alfaro de Yanahuaico, represents an attempt by Indigenous leaders to exploit this law to their own benefit, an experiment which resulted in failure. These two comunas underscore that because of resistance to the extension of centralized state power into local community affairs and the law's implicit attempt to undercut the force of growing leftist organizations, Indigenous leaders in Cayambe did not embrace the comuna form of organization.

\section{Ascazubi Alto}

The inhabitants of Ascázubi Alto founded the first legally registered comuna in Cayambe in 1938, one year after Páez promulgated the Ley de Comunas. Located in the southern part of the canton in the parroquia of Ascázubi (see Map 2), the comuna had about 400 members. In a description in 1948, demographer César Cisneros Cisneros noted that all of the comuna's inhabitants were Indigenous farmers dedicated to agricultural labor on their small plots of land on which they lived in an impoverished condition. Although their individual plots were small, the members communally held extensive tracts of pasture lands in the high páramo grasslands. Similarly, in a 1946 report, the teniente político of the local parroquia of Cangahua described the membership of the comuna as exclusively Indigenous and dedicated to agricultural labor. The community counted among its communal riches two liters a second of water from the Guanquilqui irrigation canal. Minor industries in the community included the processing of cabuya plant fibers used

\footnotetext{
${ }^{23}$ In comparison, during this same period Indians and peasants organized 156 comunas in the province of Chimborazo. Korovkin, "Indigenous Peasant Struggles," p. 29.
} 
in the construction of sandals, wool, and straw hats. Some members also worked as day laborers on neighboring haciendas. ${ }^{24}$

Bylaws from 1951 for Ascázubi Alto outline the goals of the comuna, give a fair representation of the stated purposes for this type of organization, and indicate how it was run. The comuna was to improve administration of the communal páramo lands and provide technical support for the improvement of cultivated lands. It was to create educational institutions, work on a literacy campaign, arrange for a medical dispensary, and engage in public works projects such as the construction of a community building and plaza which were necessary for the community's development. Members of the comuna included people born in the community, children born elsewhere but who lived in the community, and people who married into the community. Community members' responsibilities included sending their children to school, and contributing twenty centavos a month to be used for the construction of a school and other public works projects. In exchange, members' rights included access to communal services including the páramo pasture land and water, the right to elect leadership, economic aid in times of illness, and coverage of burial costs. ${ }^{25}$

For the most part, the administration of the comuna dealt with rather mundane issues. From the beginning, the comuna expressed a need for access to water, the construction of a road to facilitate transportation, and the construction of a small market. Occasionally there were disputes between comuneros over issues of pasture land, inheritances, and leadership. In 1943, several comuneros complained to the social welfare ministry that their president was disreputable, exploited community members, and created difficulties with a neighboring hacienda over water rights.

A registry of community members in 1944 lists 397 inhabitants of Ascázubi Alto. That same year, however, only 58 community members attended the comuna's annual meeting. This number had steadily fallen from an all-time high of 78 in attendance when the community formed the comuna in 1938. The number of people who regularly attended community meetings later stabilized around 50 people. This

\footnotetext{
${ }^{24}$ César Cisneros Cisneros, Demografía y estadística sobre el indio ecuatoriano (Quito: Tall. Graf. Nacionales, 1948), p. 192; Report from the teniente político of Cangahua, "Comuna Ascázubi Alto," Carpeta no. 55, Dirección Nacional de Desarrollo Campesino, Ministerio de Agricultura, Quito, Ecuador (hereafter DNDC/MAG).

2.5 "Reglamiento interno de la comuna Ascázubi Alto," Carpeta no. 55, DNDC/MAG.
} 
number perhaps corresponds to the number of heads of households, but the comuna legislation stipulated that both men and women were to attend. Does this drop in attendance indicate a decreasing sense of identity with the comuna form of organization? Did people not find the comuna worth the investment of time and energy? Or were most people simply too busy with other jobs and chores, and chose to allow responsibility for the comuna to be delegated to others? This lax attitude toward the comuna can be contrasted with that of the Indian workers in Pesillo who in the 1920s formed the first peasant unions in Cayambe under threat of expulsion from their hacienda.

It is possible that the micro-management of internal affairs by the national government led the community's members to realize that the ultimate purpose and function of the comuna was not to benefit the people who lived there. Rather, it was a form through which the social welfare ministry could impose its own ideas and policies into the community. Twice the ministry added a provision to Ascázubi Alto's bylaws that required members to send their children to school or risk expulsion from the comuna and loss of benefits. Twice the comuna fruitlessly attempted to void this provision. Despite the ministry's apparent good intentions, the net result for the community was its loss of autonomy and self-governance. The comuneros did not oppose the idea of educating their children, but the government schools did not respond to the Indian reality and represented an assimilationalist force designed to draw children away from their native culture. Furthermore, despite the comuna's attempts to construct a school building, they did not have access to the funding and personnel to run the school. Sending children to distant schools represented an unbearable financial burden. The comuna structure simply did not respond to local needs and initiatives.

\section{Eloy Alfaro de Yanahuaico}

In contrast to Ascázubi Alto was the short-lived comuna experiment at Eloy Alfaro de Yanahuaico in the parish of Ayora in central Cayambe. Until the mid-1990s, this was the only comuna formally established in this parish, with all others located in the southern part of the canton. On the surface, this appeared to be a fairly typical although small comuna. Its membership consisted of 38 men, 29 women, and 36 children. Its main concern was a lack of land for its members. In fact, in all probability the comuna was formed in an attempt to leverage land from the government. Even the selection of its name "Eloy Al- 
faro" was perhaps an indication that its members would be more aggressive in their demands. Eloy Alfaro was the name of the liberal general who led the 1895 Liberal Revolution and his name was associated with a defense of Indigenous issues and causes. The inhabitants founded the comuna on April 20,1944, barely a month before a popular uprising overthrew a repressive government and ushered in a period of social reforms which included the organization of a leftist labor union and Indigenous federation. This influenced the future direction of this comuna. ${ }^{26}$

The comuna's bylaws stated that it was formed in order to defend the collective interests of its inhabitants, to work for their moral and material betterment, and to improve the Indigenous race. While these goals were laudable, they were not entirely uncommon for rural highland comunas. What is more revealing was the attempt to include clauses, which the ministry of social welfare subsequently deleted. For example, article 14 of their bylaws declared the comuna to be alcoholfree and penalized members for coming to comuna meetings or other social gatherings in an inebriated state. Although previously in a context of a world-wide prohibition movement this ministry had voiced support for ending drinking in Indian communities, it now struck this aspect from the bylaws. ${ }^{27}$ Previously elites on haciendas did not want to lose the services of their contracted peon labor who would spend up to half the year in drunken festivals, whereas now with modernizing agricultural production and a surplus of labor it was more advantageous to keep these Indians who did not live on their haciendas in a drunken state. Was this an attempt to turn Indians from producers to consumers? As José Carlos Mariátegui noted in neighboring Peru, previously Indians drank only chicha, a fermented corn beverage which they made themselves at home. Now, "the production of alcohol from sugar cane is one of the most 'secure' and stable businesses of the latifundistas" who also exploited this vice to keep Indians in a subjugated state. ${ }^{28}$ Underlying this dispute are issues of control over who retains the authority to make decisions that affect a local community.

\footnotetext{
26 "Acto de formación de Eloy Alfaro de Yanahuaico," Carpeta no. 54, DNDC/MAG. All of the following details on this comuna are from documents in this folder in this archive.

${ }^{27}$ In 1925, the Ministry of Government and Social Welfare declared that alcoholism was one of the primary causes of the Indian degradation, and it was the government's responsibility to end this vice. See Julio E. Moreno, Informe del Ministerio de lo interior a la nación, 1926-1928 (Quito: Talleres Tipográficos Nacionales, 1928), p. 83; M. A. Albornoz, Informe del Ministerio de Gobierno y Previsión Social a la nación, 1930-1931 (Quito: Imprenta Nacional, 1931), p. 55.

${ }^{28}$ José Carlos Mariátegui, "The Indigenous Question," The Heroic and Creative Meaning of
} 
More significant for the history of this comuna and for the general history of popular organizational activities for the canton of Cayambe was article five of the bylaws. This article indicated that the leadership of the comuna would cultivate relations with other comunas throughout the country in order to work for the cultural advance of the people. The ultimate purpose of developing these relations was to organize a national congress of campesinos (peasants), comuneros, and montuvios (peasants from Ecuador's coastal region). Indian leaders throughout Ecuador were also pushing for similar concerns and would soon found a national federation, the Federación Ecuatoriana de Indios (FEI, Ecuadorian Federation of Indians), to struggle for Indigenous rights. ${ }^{29}$ The government understood the political intent of this organizational action and struck this article from the bylaws. The intent of the comuna legislation had been to undercut such organizational activities, not to encourage their development.

This set the tone for the direction that the comuna would soon take. Indians from Cayambe played a leading role in forming the FEI, and the time seemed right to make a dramatic push to end fundamentally unjust working and living conditions in Eloy Alfaro de Yanahuaico. The members of the community suggested that they lived in one of the most backward and impoverished areas and were in desperate need of land. On August 27, 1944, less than three weeks after the founding of the FEI, the comuna met in an emergency session and formed a commission of four people to address these concerns. Matias Arroyo, the vice president and one of the founders of the comuna, informed the government that now that they had formed a comuna they were expecting matters to improve for them. He noted that haciendas surrounded the comuna. Unlike traditional service tenancy relations which accompanied working as a huasipunguero on a hacienda, these community members were not allowed to pasture animals in the high páramo grasslands. Landholders also denied them access to natural resources such as water and firewood which agricultural workers on the haciendas had traditionally assumed to be their natural right and often formed the basis for survival strategies.

The comuna presented a proposal for a solution to their problems to the government. Nearby were two haciendas, Cariaco and Paquistan-

Socialism: Selected Essays of José Carlos Mariátegui, Edited and Translated by Michael Pearlman, Revolutionary studies (Atlantic Highlands, N.J.: Humanities Press, 1996), p. 98.

${ }^{29}$ Federación Ecuatoriana de Indios, Estatutos de la Federación Ecuatoriana de Indios (Guayaquil: Editorial Claridad, 1945). 
cia, which the government owned and were administered as part of the Asistencia Pública (Public Assistance) program within the same ministry of social welfare under which the comuna had been organized. A liberal government had confiscated these haciendas from the Catholic Church in 1908, and the proceeds from their exploitation were to fund welfare projects such as hospitals and orphanages. Eloy Alfaro de Yanahuaico asked the government to give the comuna some land from these haciendas. After all, the government had sold the neighboring Tupigachi hacienda to retired military personnel and had similarly divided up government-owned haciendas elsewhere in the country. ${ }^{30}$ The government flatly refused. The haciendas were rented to landlords for an eight-year period, and Cariaco was at the end of its lease. The comuna proposed that perhaps the government would rent them this hacienda. The proposal received no official action.

Members of the community were beginning to become desperate. What possible course of action remained open to them? José María Velasco Ibarra had returned to power in May 1944 based on the support of the lower classes, but he had turned on his former allies and now completely supported the wealthy conservative capitalist elite. Ecuador was experiencing an economic boom based on banana production, but none of this wealth trickled down to the Indigenous peasantry. The members of the comuna had lost all faith in both the government and their existing leadership to solve these problems and therefore sought out new and more radical leadership. Members of the community gathered on November 20,1948 , to elect a new executive council. No one who was elected at this meeting had previously appeared on the comuna's membership roles, and they were probably not permanent residents in the community. Dolores Cacuango was unanimously selected to serve as the president, as were Aquiles Quishpe for vice president and José Campúes for treasurer. By a majority vote Luis Catucuamba won the position of secretary and Abiquel Quishpe the position of sindico (trustee).

Cacuango, the woman they brought in to lead the comuna, was a veteran of Indigenous struggles in the canton of Cayambe and one of the primary symbols of Indigenous resistance in Ecuador. She was born on the Pesillo hacienda in the northern part of the canton of

\footnotetext{
${ }^{30}$ Edmundo Pérez Guerrero, Colonización e inmigracion en el Ecuador (Quito: Edit. Casa de la Cultura Ecuatoriana, 1954), p. 151.
} 
Cayambe in 1881. Like most Indigenous peoples born in the nineteenth century, she had to work from a very young age and never attended school or learned to read or write. Although illiterate, she fought tirelessly for schools for Indigenous communities and was instrumental in setting up the first bilingual schools in Cayambe. Cacuango maintained an active presence organizing meetings of hacienda workers and demanding land rights. She played a leading role in strikes at Pesillo in 1931 and rose to a position of leadership in the struggle against the hacienda system. A hacienda administrator complained that "this pernicious woman" helped Indians build houses on hacienda land even though they did not have a formal contract to do so. ${ }^{31}$ A newspaper article from the 1940 s described her as at the head of Indigenous struggles, the last to retreat, and always ready to suffer for the cause. ${ }^{32}$ Because of these activities, Velasco Ibarra threatened to exile her to the Galápagos Islands in 1946. The local priest in Cayambe attempted to bribe her so that she would stop leading Indigenous revolts, but she continued her work for a more just society. ${ }^{33}$ Cacuango was actively involved in broader political struggles in the country, including leading the May 1944 revolution in Cayambe, founding and leading the FEI, and serving on the Central Committee of the Ecuadorian Communist Party for which the government later imprisoned her. ${ }^{34}$

A week later, Manuel Rodríguez, the teniente político for the parish of Ayora, sent a note to the undersecretary of social welfare. He claimed that the comuna could not continue to function because its

\footnotetext{
${ }^{31}$ Letter from Juan Francisco Sumárraga to Director, Junta Central de Asistencia Pública (JCAP), March 21, 1946, in Correspondencia Recibida, Segundo Semestre, Segundo Parte, 1946, p. 1555, Archivo Nacional de Medicina del Museo Nacional de Medicina "Dr. Eduardo Estrella," Fondo Junta Central de Asistencia Pública in Quito, Ecuador (hereafter JCAP); Letter from C. Anibal Maldonado, Administrador, to Jefe, Departmento de Haciendas, Asistencia Pública, October 10, 1946 (Oficio no. 27), in Correspondencia Recibida, 1946, JCAP. For basic biographical data on Dolores Cacuango, see Osvaldo Albornoz Peralta, Dolores Cacuango y las luchas indigenas de Cayambe (Guayaquil: Editorial Claridad S.A., 1975), and Raquel Rodas, Crónica de un sueño: las escuelas indígenas de Dolores Cacuango: una experiencia de educación bilinge en Cayambe (Quito: Proyecto de Educación Bilinge Intercultural, MEC-GTZ, 1989).

32 "Dolores Cacuango," Antinazi (Quito) 2:19 (April 17, 1943), p. 4, facsimile edition in Raymond Mériguet Cousségal, Antinazismo en Ecuador, años 1941-1944: autobiografía del Movimiento Antinazi de Ecuador (MPAE-MAE) (Quito: R. Meriguet Coussegal, 1988), p. 214.

${ }^{33}$ Rodas, Crónica de un sueño, p. 63.

${ }^{34}$ A photo in Elías Muñoz Vicuña, Masas, luchas, solidaridad, Colección Movimiento Obrero Ecuatoriano; No. 8 (Guayaquil: Universidad de Guayaquil, 1985), p. 91, of a Central Committee meeting in Quito, July 26-28, 1947, shows seventeen people, of which Cacuango is one of three women and the only Indigenous person.
} 
members had not properly cared for it and were unconcerned about the direction it took. A letter from Segundo Cabezas, who had served as president of the comuna since its founding, was more specific in his complaints. The November 20 meeting which elected the new cabildo violated the 1937 Ley de Comunas on two counts: it did not meet in the month of December, as stipulated in article 11, and the teniente político was not present at the meeting, as required in article 12. A dissident faction sought to run the comuna independently of central governmental rule. Everything was out of control, he said, and he could do nothing about it.

After this correspondence, the comuna of Eloy Alfaro de Yanahuaico disappeared from government records. It proved such a threat to the established order that the social welfare ministry dissolved the comuna and assigned its administrative number to another comuna. Eloy Alfaro de Yanahuaico, therefore, does not appear in any lists of active or inactive comunas. It provides, however, an example of a local Indigenous community attempting to utilize this legal framework to claim control over its own affairs and the government responded by refusing to allow that to happen. It indicates that the government believed that the purpose of this community was not to encourage dissent, but to provide for a means for central government control over and intrusion into local community affairs. The failure of this experiment in using this organizational form to force social changes assured that in the future Indigenous leaders in Cayambe would not look to this system to improve their lives.

This development perhaps retarded but did not entirely halt the formation of other comunas in the canton of Cayambe. In December of 1944, eight months after the formation of Eloy Alfaro de Yanahuaico but several years before it ceased to exist, Paccha Pucará become the third comuna in Cayambe to legally incorporate itself. As with Ascázubi Alto, it was located in the southern parroquia of Cangahua and also represented a rather traditional trajectory for comunas in this area of the country. Members of this comuna worked as day laborers on the neighboring Carrera and Pisambilla haciendas. The land which they owned never was part of a hacienda. Rather, it was marginal land at the agricultural frontier which the comuneros brought under cultivation. ${ }^{35}$ After Paccha Pucará, 11 more years passed before the next

\footnotetext{
${ }^{35}$ Cisneros, Demografia, p. 192. Later, Paccha Pucará divided into two comunas with one taking the name "Paccha" and the other "Pucará."
} 


\section{Comunas and Indigenous Protest in Cayambe, Ecuador}

comuna legally incorporated itself in the canton of Cayambe. Only four more communities in Cayambe were to organize themselves as comunas before the 1964 agrarian reform law.

\section{A Critique of Comunas}

A study of popular organizations in Ecuador defined the comuna as "the oldest form of peasant organization, with pre-colonial and colonial origins." It was the result of the merging of an Inka form of social organization (the ayllu) with that which the Spanish conquest imposed (the comuna). Despite the legal requirements and organizational structures, according to this analysis, the comunas preserved a large part of traditional Indigenous governing mechanisms, including redistributive and exchange networks and other aboriginal social structures. ${ }^{36}$ Many scholars have traditionally adhered to this interpretation, but it ignores the type of traditional community organization in Cayambe.

Located in northern Ecuador, Cayambe had been incorporated into Tahuantinsuyo, the Inka empire, only within a generation of the Spanish conquest and only after a 17-year long and bloody battle against the invaders. Very little research has been conducted on the nature of Cayambe's social organization before these two conquests, but there is no indication that they utilized the ayllu form of organization. In all probability, the Spanish, with their Cuzco-centric view of the Andes, imposed this label on communities it sought to subdue after the 1569 Toledan reforms. ${ }^{37}$ As the pan-Indian organization Confederación de Nacionalidades Indígenas del Ecuador (CONAIE) noted, the Spanish conquest fundamentally and irreparably disrupted the traditional social structure on which the government allegedly constructed the cor munas. ${ }^{38}$ Some earlier scholars, perhaps inadvertently, had given cre-

\footnotetext{
${ }^{36}$ Instituto de Estudios Ecuatorianos (IEE), Políticas estatales y organización popular (Quito: Instituto de Estudios Ecuatorianos, 1985), pp. 124-25.

${ }^{37}$ Salomon notes that early informers in northern Ecuador simply refused to use Inka terms like "ayllu." See Frank Salomon, Native Lords of Quito in the Age of the Incas: The Political Economy of North Andean Chiefdoms (Cambridge: Cambridge University Press, 1986), pp. 14, 122 and 173. Similarly, Powers recognizes the foreign origins of this concept but utilizes the term because of the success of the Spanish colonial power in imposing the label. Karen Vieira Powers, Andean Journeys: Migration, Ethnogenesis, and the State in Colonial Quito (Albuquerque: University of New Mexico Press, 1995), p. 12. Caillavet cautions against the inappropriateness of using foreign terminology to understand a local reality. Chantal Caillavet, "La adaptación de la dominación incaica a las sociedades autóctonas de la frontera septentrional del Imperio: (Territorio Otavalo-Ecuador)," Revista Andina (Cuzco) 3:2 (December 1985), 419.

${ }^{38}$ Confederación de Nacionalidades Indígenas del Ecuador (CONAIE), Las nacionalidades
} 
dence to the view of the comuna as a fundamentally European rather than Indian construct when they traced the legal tradition of this law back to Spanish colonial administration rather than traditional Indigenous community structures. ${ }^{39}$ Diego Iturralde consciously traced the cabildo system of governance as a legacy of Spanish colonial administrative structures which Simón Bolívar attempted to impose on Indian communities to retain control over them. ${ }^{40}$ With little identification with any aspect of the structure this legislation created, it is not hard to understand why communities in Cayambe would not anxiously embrace it. The provisions of the law were far removed from their socio-cultural reality.

A second and more fundamental critique of the comuna legislation concerned its extension of state power one step further into the local community. The national government in Quito directly appointed officials who oversaw local affairs, the teniente político on the parish level and the jefe político at the larger canton level. They were civilmilitary authorities who had the power to impose fines and to make arrests. The person appointed to these positions was always a "mestizo bien blanco," a person who culturally came from an elite class. ${ }^{41}$ Together with the local parish priest, who was also either a white or mestizo, the teniente político and jefe político worked hand-in-hand with the large landholders (hacendados) to consolidate control over rural society. By the mid-nineteenth century, these secular authorities had displaced the power of the traditional ethnic lords (alternatively called kurakas or caciques).$^{42}$ No one in the Indian communities had any control over these appointed officials who were notorious for their abusive behaviors and represented the extension of coercive white state power into local Indian communities.

indigenas en el Ecuador: Nuestro proceso organizativo, 2d ed. (Quito: Ediciones Abya-Yala, 1989), pp. 31 and 131.

${ }^{39}$ See chapter two ("Las comunas indígenas") in Piedad Peñaherrera de Costales and Alfredo Costales Samaniego, "Comunas juridicamente organizadas," Llacta (Instituto Ecuatoriano de Antropología y Geografía (IEAG), Quito) 15 (November 1962), pp. 48-66.

${ }^{40}$ Diego A. Iturralde, Guamote: campesinos y comunas, Colección Pendoneros, No. 28 (Otavalo, Ecuador: Instituto Otavaleño de Antropología, 1980), p. 113. See Art. 18 of Simón Bolívar, "Establecimiento de la contribución personal de indígenas," in Nueva Historia del Ecuador, Volumen 15: Documentos de la historia del Ecuador, ed. Enrique Ayala Mora (Quito: Corporación Editora Nacional, 1995), p. 116.

${ }^{41}$ Moisés Sáenz, Sobre el indio ecuatoriano y su incorporación al medio nacional (México: Publicaciones de la Secretaría de Educación Pública, 1933), pp. 130-31.

${ }^{42}$ Andrés Guerrero, Curagas y tenientes políticos: La ley de la costumbre y la ley del Estado (Otavalo 1830-1875) (Quito: Editorial El Conejo, 1990). 
The comuna legislation indicated that the central government was no longer willing to allow its power and control to stop at the parish level. Through the maintenance of registries of comuna members and property, the government converted community members into agents of state power. The teniente político was to control and administer the local cabildo. The teniente político (and if he was not available, the jefe político from the canton) were to preside over the annual comuna meetings, monitor elections of the cabildo, and communicate these results to the central government. It was easy for the teniente politico (sometimes in coordination with the parish priest) to manipulate the voting process for the cabildo in order to assure that malleable persons responsive to governmental demands would be in charge of the comuna. The presence of foreign authorities such as the teniente político who controlled the election of community authorities and mediated internal conflicts caused resentment in Indian communities. ${ }^{43}$ The Ley de Comunas explicitly expressed an intent to control and negate local decisions if they were not favorable or convenient to the government. Article 14 reserved for the social welfare ministry the right "to elect a different cabildo which successfully represents the interests of the comuna." 44

As a result, communities would end up with cabildos which served the government's interests rather than that of the community. The leaders would not consult the community on issues which concerned them, and would become authoritarian and create serious internal tensions in the community. The people selected to lead the comuna did not represent the traditional leadership of the community. The government intentionally utilized the comuna legislation to undermine and replace these traditional authority figures ${ }^{45}$ Often the result was parallel authority structures, with the traditional authorities coming into conflict with the one which the government imposed. This would further lead to a sense of alienation among community members toward the comuna structure, partially because the entire process of selecting leaders by voting rather than through consensus and traditional authority lineages was foreign to the normal decision-making process and partially because the resulting leaders reflected the intru-

\footnotetext{
${ }^{43}$ CONAIE, Las nacionalidades indígenas, p. 131.

44 "Ley de Organización y Régimen de las Comunas," p. 1518.

${ }^{45}$ Malo, Memoria, anexo no. 5, p. 37-38, and Carlos Andrade Marín, Informe que el Ministro de Previsión Social y Trabajo presenta a la nación, 1941 (Quito: Talleres Gráficos de Educación, 1941), p. 103.
} 
sive state power which the government wielded rather than embracing the community's interests and concerns.

Without authority (sometimes called poder convocatorio or convocatory power), comuna leaders were unable to mobilize support for community projects. For example, Segundo Basilio Flores, the president of the comuna of Chinchinloma in the southern parish of Santa Rosa de Cusubamba in Cayambe, complained to the social welfare minister that the community members did not comply with their obligations including participating in assemblies and communal work parties (mingas). He requested that a governmental official visit the comuna and compel the members to follow his directions. ${ }^{46}$ Without a sense that the comuna benefitted the community, interest and participation in the comuna declined and sometimes comunas would disappear entirely. This was not because of reactionary, isolationist, or traditionalist attitudes, but the result of a government in which they had no voice or citizenship rights which now wanted to micro-manage their local affairs. From this recognition, it was one small step to reject entirely the comuna structure.

Resistance to government control over local affairs extended beyond Cayambe. Osvaldo Hurtado determined that in 1972 only 47 percent of the comunas in Ecuador had sent the names of their cabildos to the social welfare ministry. One interpretation of this statistic was that the comunas had ceased to function and therefore had not elected new leaders. Hurtado raises an alternative interpretation that due to negligence or in order to avoid expenses the comuna had held their election without the presence of the teniente político, the local governmental official who normally communicated this information to the ministry ${ }^{47}$ An alternative explanation which Hurtado does not directly consider is that Indigenous community structures functioned perfectly well without outside intervention and thus saw the presence of the teniente político to be unnecessary and perhaps even resented the meddling of governmental officials in local affairs. Some communities formed comunas but never officially registered them with the government and thus remained beyond the reach of the patronizing and assimilating state structure. After all, what benefits did this inter-

\footnotetext{
${ }^{46}$ Letter from Segundo Basilio Flores to Ministerio de Previsión Social y Comunas, 13 February 1970 , Carpeta no. 111, DNDC/MAG.

${ }^{47}$ Hurtado, Organización popular, p. 15.
} 
vention bring to the community? Not communicating this information became what James Scott called an everyday form of resistance to the insertion of central governmental control and state structures into a local community.

Not only did the comuna legislation represent a negation of traditional authority structures, it was also originally designed as an attack on independent leftist political organizing efforts. The comuna legislation must be understood within the context of the type of extension of state power which its authors desired. Insistence that the teniente político monitor elections and that the comuna send inventories of its belongings and the names of its inhabitants and leaders to a central ministry meant that the government would more easily be able to monitor and stop leftist organizing efforts in the communities. The government attempted to exercise direct control over peasant organizations in order to shield them from the influence of labor and other more radical organizations. As was apparent with Eloy Alfaro de Yanahuaico, the government was not interested in organizations which operated independently of its control. Comunas had always been designed to draw rural communities away from dissident organizations.

The government had an authoritarian intent in establishing regulations covering the governing of comunas, with the power to modify or reject organizational structures which were not to their liking. According to the Instituto de Estudios Ecuatorianos (IEE), this was because traditional Indigenous forms of social organization were "considered anachronistic and a bad habit left over from the past." 48 Rather than preserving local social, cultural, and economic values, the Ley de Comunas had a strong modernizing intent that sought to bury Ecuador's Indigenous past in favor of assimilating rural communities into an emerging capitalist order.

All of this is not to imply that Indigenous leaders in Cayambe and their supporters never used the comuna structure to advance their own social and political interests. A politically astute leader and organizer will be able to use any available tools to advance the community's interests. For example, in 1971 ex-huasipungueros invaded the hacienda La Libertad in the parish of Cangahua to claim land for their comuna. Pedro Miranda, the owner of the hacienda, denounced the

\footnotetext{
${ }^{48}$ IEE, Políticas estatales, p. 135.
} 
Indians as working against the economic development of Ecuador and in favor of subversion, disorder, and chaos. Miranda claimed that Dr. Bolaños from the FEI was behind the formation of this comuna and was using it to attack his interests. ${ }^{49}$ Increasingly, the FEI took an active interest in utilizing the comuna structure as a means to press their agenda for a redistribution of land and a true agrarian reform, particularly in areas of the country where previously the organization had not had a strong presence. Some Indians were able to utilize the comuna structure for their own ends, including defense of their economic, political, and ethnic interests. ${ }^{50}$

Although the government claimed this legislation would assist communities with their social, moral, intellectual, and material development, ultimately its intent was to incorporate small population centers into the country's formal political and administrative structures. Its goal was to draw communities into a national cash economy and increase their dependency on outside forces to the benefit of the white elites while at the same time negating leftist organizing efforts. The net effect was an attack on Indigenous autonomy, self determination, traditional authority structures, and cultural identity. Indian communities stood to gain little from such a move. The battle over comunas represented a division between two fundamentally different visions for the nature of political, economic, and social structures to be constructed in Ecuador.

The 1937 Ley de Comunas proved to be a conservative force in rural society, and Indigenous leaders in Cayambe recognized the legislation for what it was. They applied a critical political analysis to the situation. As the failed attempt at Eloy Alfaro de Yanahuaico demonstrated, this legislation would not lead to the long-needed profound structural changes in society. Within the context of a paternalistic society, this law would only prove to deepen Indigenous dependency on the dominant culture. It did not open the way for cultural rejuvenation

\footnotetext{
${ }^{49}$ Letter from Pedro Miranda to the Ministerio de Previsión Social, Trabajo, y Comunas, 29 March 1971, Carpeta no. 144 (Miranda La Libertad), DNDC/MAG. For other examples of Indian activists who used the comuna structure to advance their political goals, see A. Kim Clark, "New Strategies of Resistance in the Ecuadorian Highlands: Peasant Actions and Discourse, 19301950," unpublished manuscript

${ }^{50}$ Despite the original limitations of the law, Roberto Santana maintains that recently Indians have transformed it from legislation "a los" Indians to "de los" Indians. Santana, ¿Ciudadanos en la etnicidad?, pp. 114-15.
} 
558 Comunas and Indigenous Protest in Cayambe, Ecuador

or defense of ethnic interests, but represented an assimilating force which worked against their own self interests. The Ley de Comunas did not provide for access to land, political autonomy, or economic self sufficiency. Those in Cayambe who wished to gain political space for Indigenous rights issues were forced to look elsewhere for avenues through which they could reach these goals.

Gettysburg College

MARC BECKeR

Gettysburg, Pennsylvania 
Appendix : Location and Date of Legal Registration of Comunas in Cayambe

\begin{tabular}{|c|c|c|}
\hline Comuna & Parroquia & Date of Registration \\
\hline Ascázubi Alto & Ascázubi & September 23,1938 \\
\hline Paccha & Cangahua & December 30, 1944 \\
\hline Pucará & Cangahua & December 30, 1944 \\
\hline Carrera & Cangahua & April 21, 1955 \\
\hline Monjas Alto & Juan Montalvo & May 14,1955 \\
\hline Sayaro & Juan Montalvo & December 10, 1960 \\
\hline Chinchinloma & Santa Rosa de Cusubamba & March 21, 1962 \\
\hline Guachalá & Cangahua & April 26, 1968 \\
\hline Porotog & Cangahua & March 25, 1969 \\
\hline San Pedro de Cangahua & Cangahua & April 11, 1971 \\
\hline Chaupiestancia & Otón & September 20, 1971 \\
\hline Miranda La Libertad & Cangahua & November 1, 1971 \\
\hline San José & Cangahua & April 7, 1972 \\
\hline Cochapamba & Cangahua & August 9, 1972 \\
\hline Chambitola & Cangahua & August 9, 1972 \\
\hline Cangahuapungo & Santa Rosa de Cusubamba & July 7,1976 \\
\hline San Luis de Guachalá & Cangahua & May 18,1979 \\
\hline El Llano & Otón & October 14,1981 \\
\hline Coniburo & Cangahua & December 21, 1981 \\
\hline Candelaria & Cangahua & April 18, 1984 \\
\hline Izacata & Cangahua & April 16, 1985 \\
\hline Milagro & Cangahua & May 19,1989 \\
\hline San Francisco de Otoncito & Otón & March 25, 1993 \\
\hline Chumillos & Cangahua & July 26,1994 \\
\hline Hato de Chaupiloma & Juan Montalvo & September 6, 1994 \\
\hline Cariacu & Ayora & February 7, 1995 \\
\hline Pisambilla & Cangahua & October 13,1995 \\
\hline Santo Domingo No. 2 & Ayora & March 7, 1996 \\
\hline
\end{tabular}

Source: Comunas Jurídicas de la Provincia de Pichincha, Cantón Cayambe, Dirección Nacional de Desarrollo Campesino, Ministerio de Agricultura, Quito. 